\title{
Características tecnológicas de glúten vital de diferentes qualidades
}

\author{
Gabriela Paiva Corrêa (IC), Fernanda Ortolan (PG), Caroline Joy Steel (PQ)
}

\section{Resumo}

No Brasil, o glúten vital (GV) é usado para melhorar as características reológicas de farinhas inadequadas à panificação, porém é comercializado com poucas informações referentes à sua qualidade. O objetivo deste trabalho foi avaliar as características tecnológicas de GV de diferentes origens (GVA e GVB) através de testes reológicos e de panificação. GVA apresentou os melhores resultados quando comparado a GVB, reforçando a existência de diferenças na qualidade dos glútens vitais comercializados.

Palavras Chave: Glúten vital, Panificação, Análises reológicas.

\section{Introdução}

A utilização de glúten vital tem por finalidade melhorar as características reológicas de farinhas consideradas inadequadas para a elaboração de pães.

A qualidade deste produto está associada às proteínas que o constituem (gliadinas e gluteninas), responsáveis por suas características viscoelásticas. Embora muito utilizado no Brasil, o glúten vital é comercializado com poucas informações referentes à sua qualidade.

Desta forma, o objetivo deste trabalho foi avaliar as características tecnológicas de glúten vital de diferentes origens (GVA e GVB) através de testes reológicos (farinografia, alveografia e extensografia) e testes de panificação pela fortificação de farinha de trigo com níveis de 5 e 7 $\%$ de glúten vital.

\section{Resultados e Discussão}

Observando as características reológicas das farinhas fortificadas com glúten vital de diferentes origens, foi possível verificar que a adição de GVA ou GVB nos 2 níveis estudados melhorou a qualidade reológica em comparação à farinha de trigo controle.

Pela análise farinográfica, observou-se aumentou da absorção de água, do tempo de desenvolvimento e da estabilidade da massa. Os maiores valores para estes parâmetros foram obtidos pela farinha fortificada com $7 \%$ de GVA.

Analisando os resultados alveográficos, observou-se que as farinhas fortificadas com glúten vital (GVA e GVB) apresentaram maior elasticidade e extensibilidade da massa, refletindo em aumento da força de glúten, quando comparadas à farinha controle.

Os parâmetros extensográficos aumentaram com a adição de glúten vital à farinha de trigo, em especial, aos 135 minutos da análise, quando os valores de resistência, resistência máxima e energia das mesclas apresentaram resultados maiores quando comparados à farinha de trigo controle, sendo maiores para as mesclas com 7 $\%$ de fortificação de glúten vital, tanto GVA quanto GVB.

Quando os pães obtidos das farinhas fortificadas com 5 e $7 \%$ de GVA ou GVB foram avaliados, foi possível observar que apenas o pão elaborado com $7 \%$ de GVA apresentou volume específico que diferiu do pão elaborado com farinha de trigo controle, os demais pães apresentaram-se estatisticamente iguais ao controle

Segundo Delcour et al. (2012), a adição de glúten vital às farinhas contribuiu para melhorar as características das massas formadas, pois o aumento do teor de proteínas formadoras da rede de glúten possibilita o fortalecimento da massa, devido a interações covalentes e não-covalentes entre as proteínas da farinha fortificada e do glúten vital intencionalmente adicionado.

\section{Conclusões}

Através das técnicas realizadas, foi possível observar que as farinhas de melhor qualidade para panificação foram às mesclas com a adição de glúten vital $A$, quando comparadas às mesclas com adição de glúten vital $B$, reforçando a existência de diferenças na qualidade dos diferentes glútens comercializados no Brasil.

\section{Agradecimentos}

Os autores agradecem ao CNPq pela concessão das bolsas de Iniciação Científica e de Doutorado, ao Moinho Sul Mineiro pela doação de farinha de trigo, e à Labonathus e Granotec pela doação dos glútens vitais utilizados nesse projeto.

${ }^{1}$ AACCI. American Association of Cereal Chemists. Approved methods, 11th ed., St. Paul, AACC, 2010

DELCOUR, J.A.; JOYE, I.J.; PAREYT, B.; WILDERJANS, E.; BRIJS, K.; LAGRAIN, B. Wheat gluten functionality as a quality determinant in cereal-based food products. Ann. Review Food Science and Technology, v.3, p.469-492, 2012. 